\title{
Role of Extracellular Proteases in Biofilm Degradation Produced from Escherichia coli and Pseudomonas mendocina
}

\author{
Poonam Kumari $^{1 *}$, Savita Jandaik ${ }^{2}$ and Sudha Batta ${ }^{3}$ \\ ${ }^{1}$ Department of Microbiology Shoolini University, Solan (H.P)-173212, India \\ ${ }^{2}$ Department of Plant Pathology, University of Horticulture and Forestry, \\ Nauni Solan(H.P)-173212, India \\ ${ }^{3}$ Department of Microbiology Shoolini Institute of Life Sciences and Business Management, \\ Solan, India \\ *Corresponding author
}

\section{A B S T R A C T}

One of the most important properties of the protease enzyme is to degrade the biofilm because removal of biofilms is very difficult. In industrial settings, both the inactivation

\begin{tabular}{|l|}
\hline Key w or d s \\
Alkaline protease, \\
Bacillus subtilis, \\
Biofilm, \\
Polysaccharide \\
\hline Article Info \\
\hline $\begin{array}{l}\text { Accepted: } \\
\text { 15 May } 2018 \\
\text { Available Online: } \\
10 \text { June } 2018\end{array}$ \\
\hline \hline
\end{tabular}
and removal of biofilms are of huge concern. If only disinfection without the removal of attached biofilms occurs, the inactivated biofilm cells may provide an ideal environment for further adhesion and growth, resulting in a complex matrix. Microbial resistance to biocides and their negative environmental impact are the main reasons for finding alternative biofilm control strategies. Enzymes are highly selective and capable of distrupting the structural stability of the biofilm EPS (extracellular polymeric substance) matrix. The biofilms acts as a barrier for antibiotics to affect the pathogenic bacteria and this may account for some people developing chronic Borreliosis/ Lyme symptoms. However proteolytic enzymes are very effective at dissolving mucupolysaccharides in biofilm. The $0.2 \mathrm{ml}$ of purified alkaline protease of molecular weight of $29 \mathrm{kDa}$ has been applied for degrading the biofilm of Pseudomonas or E.coli in 10 minutes. When biofilm was treated with the thermophilic protease enzyme the growth of bacteria producing biofilm was minimum (E.coli 0.230 at $\mathrm{A}_{660 \mathrm{~nm}}$ and Pseudomonas mendocina 0.120 at A $660 \mathrm{~nm})$. The combination of protease and polysaccharides was successful in biofilm removal or detachment of the organisms.

\section{Introduction}

Enzymes played a significant role in several aspects of life from time immemorial. They are in fact vital for the existence of life itself. Enzymes play crucial role in producing the food we eat, the clothes we wear and even in producing fuel for our automobiles. They are important in combating environmental pollution. Leather processing is one of the important industries closely related to everyday life. Proteases are the most important industrial enzymes that execute a wide variety of functions and are thus employed in many important biotechnological applications (Joshi, 2010). They constitute two third of the total enzymes used in various industries and at least a quarter of the total global enzymes production (Banik et al., 2004). These enzymes occupy a pivotal position due to their wide applications in food processing, pharmaceuticals, peptide synthesis 
and leather processing (Kalaiarasi et al., 2009) Use of enzymes for industrial processing has received considerable attention in recent years (Ibrahim et al., 2009). Pseudomonas aeruginosa and Escherichia coli are the most prevalent Gram-negative biofilm forming medical device associated pathogens (Cole et al., 2014). Its presence in food and food environments is not regulated, but because of its good biofilm-producing ability it easily colonizes in pipes, heat-exchangers, airconditioners, etc. Pseudomonas aeroginosa form biofilm in many milk storage tanks and milk storage lines.

\section{Materials and Methods}

Sample collection and revival of protease producing organism

Protease producing microorganisms (Bacillus subtilis) was collected from Microbiology department of SILB, Solan which was isolated and optimized previously.

Qualitative analysis for the proteolytic activity

Bacillus subtilis was spot inoculated on skim agar and plate was inoculated at $50^{\circ} \mathrm{C}$ for 24 48 hrs. After incubation, plates were observed for the clearing zone around the colony which indicated the proteolytic activity of the test bacterial culture.

\section{Quantitative analysis}

Protease production was done by using medium containing (g/l) glucose-2.0, casein0.5 , peptone-0.5, and yeast extract-0.5, $\mathrm{KH}_{2} \mathrm{PO}_{4}-1.0, \mathrm{MgSO}_{4}-0.5$ and $\mathrm{FeSO}_{4} 7 \mathrm{H}_{2} \mathrm{O}-$ 0.1 . Erlenmeyer flasks containing $50 \mathrm{ml}$ sterilized medium was inoculated with $5 \mathrm{ml}$ suspension of culture. The flasks were incubated at $50{ }^{\circ} \mathrm{C}$ for $48 \mathrm{hrs}$ at $120 \mathrm{rpm}$ in rotary shaker. After incubation, content was centrifuged at $10,000 \mathrm{rpm}$ for $10 \mathrm{~min}$ and supernatant was used as a source of enzyme.

\section{Enzyme activity}

Protease activity was determined by using skim milk according to the method Leighton et al., 1973. The reaction mixtures containing $250 \mathrm{ml}$ of $1 \%(\mathrm{w} / \mathrm{v})$ skim milk as a substrate , $250 \mathrm{ml}$ of $0.5 \mathrm{M}$ Tris buffer $\mathrm{pH} 9.0$ and $250 \mathrm{ml}$ of culture supernatant was incubated at $50^{\circ} \mathrm{C}$ for $10 \mathrm{~min}$. The reaction was stopped by the addition of $3 \mathrm{ml}$ of $5 \%(\mathrm{w} / \mathrm{v})$ trichloroacetic acid. Then each tube was centrifuged at $10,000 \mathrm{rpm}$ and the absorbance of the supernatant was taken at $275 \mathrm{~nm}$. One unit of the enzyme activity (U) was equal to the amount of cell free supernatant required to increase absorbance at $275 \mathrm{~nm}$ by one unit under the assay condition. Protein content was estimated by method of Lowry by using Bovine serum albumin as the standard.

\section{Protein estimation}

The protein estimation was determined by the Lowry method by using bovine serum albumin as a standard (Lowry et al., 1951).

\section{Biofilm production}

The standard biofilm producing bacterial strains i.e. E.coli (MTCC-1687) and Pseudomonas mendocina (MTCC-11808) was procured from the Microbial Type Culture Collection (MTCC), IMTECH Chandigarh. For the biofilm formation the cells were grown in micro titre plate for the desired period of time and then the wells were washed to remove planktonic bacteria. Remaining cells adhered to the wells were subsequently stained with a dye that allows visualization attachment pattern. This surface associated dye was also be solubilized for semi quantitative assessment of the biofilm formed. Pseudomonas mendocina and E.coli culture 
was inoculated in 3 to $5 \mathrm{ml}$ tryptic soya broth and incubated at $37^{\circ} \mathrm{C}$ for $24 \mathrm{hrs}$. This served as inoculum.

\section{Biofilm degradation}

The fundamental base for all biofilm studies is the use of appropriate cultivation techniques. Biofilm formation and quantification using glass test tubes was measured. Briefly, overnight cultures of Pseudomonas mendocina and E.coli, $200 \mu \mathrm{l}$ inoculated in biofilm growth medium and incubated overnight at $37^{\circ} \mathrm{C}$. To screen for the efficiency of enzyme in removing the biofilm; the enzyme treatment was given in two ways such as in the medium during the incubation, and after the incubation at $37^{\circ} \mathrm{C}$. After incubation, the growth medium was gently mixed by adding $2 \mathrm{ml}$ of cleaning solution $\left(45^{\circ} \mathrm{C}\right.$ water was used as control) and incubated the tubes for 30 mins.

After which the solution was gently pipette out. Than $2 \mathrm{ml}$ water and $200 \mu \mathrm{l}$ of $0.1 \%$ crystal violet solution was added in each tube and incubated for $15 \mathrm{mins}$. Later the tubes were rinsed three times with water. Crystal violet stained biofilms were solubilised in $400 \mu 1$ ethanol and thus formed crystal violet ethanol solutions were measured for absorbance at $595 \mathrm{~nm}$.

\section{Results and Discussion}

A total of 15 bacterial isolates were obtained (Table 3.1), from soil and water samples. The results depicted in table 3.2 shows that out of 15 isolates only 8 bacterial isolates (ATP-P1, ATP-P3, ATP-P5, ATP-P6, ATP-P7, ATPP11, ATP-P12, and ATP-P14) hydrolyzed the casein (Figure 3.1). The maximum casein hydrolysis was observed with a bacterial isolate ATP-P5 In the research work. The maximum casein hydrolysis and proteolytic activity was observed with a bacterial isolate ATP-P5 (2.0 IU/ml) Table 3.1.

\section{Identification}

After gram's staining, the culture was observed purple colour Gram +ve rods (Fig 3.2), So it was confirmed that the isolated culture was Bacillus sp.

Assay of proteolytic activity and protein estimation

Bacterial isolate ATP-P5 was inoculated individually in Glucose yeast casein broth enriched with casein. The inoculated broth was incubated at $50^{\circ} \mathrm{C}$ under shaking (120 rpm). The cell free broth was harvested and tested for the protease activity at $\mathrm{A}_{280}$ (Table 3.2). Specific activity was observed after the protein estimation and enzyme activity. One unit of enzyme activity (U) was calculated as the amount of cell-free supernatant required to increase absorbance at $275 \mathrm{~nm}$ by one unit under the assay conditions. Protein content was estimated by method of Lowery's using bovine serum albumin as the standard and found to be $1.5 \mathrm{IU} / \mathrm{mg}$ (figure 3.2).

\section{Biofilm formation and quantification}

To screen for the efficiency of enzyme in removing the biofilm; the enzyme treatment was given during the incubation, at $45^{\circ} \mathrm{C}$.

The cultures of E. coli MTCC-1687 and Pseudomonas mendocina MTCC-11808 was grown on nutrient agar plates for the detection of biofilm production on Nutrient agar plate (Figure 3.3).

\section{Detection of Biofilm production from the selected organism by different methods}

\section{Tube method}

By Tube method, visible thick film was obtained inside the wall of tube and bottom of the tube (Figure 3.4). 
Table.1 Screening of bacterial isolates for protease production

\begin{tabular}{|c|c|c|c|}
\hline Sr No & Isolates & Zone of clearance & Activity (IU/mI) \\
\hline 1 & ATP-P1 & + & $0.7 \pm 0.1$ \\
\hline 2 & ATP-P2 & - & $0.8 \pm 0.3$ \\
\hline 3 & ATP-P3 & + & $1.8 \pm 0.2$ \\
\hline 4 & ATP-P4 & - & $0.6 \pm 0.4$ \\
\hline 5 & ATP-P5 & +++ & $2.0 \pm 0.1$ \\
\hline 6 & ATP-P6 & + & $0.8 \pm 0.2$ \\
\hline 7 & ATP-P7 & + & $0.5 \pm 0.1$ \\
\hline 8 & ATP-P8 & - & $0.7 \pm 0.08$ \\
\hline 9 & ATP-P9 & - & $0.8 \pm 0.2$ \\
\hline 10 & ATP-P10 & - & $0.2 \pm 0.1$ \\
\hline 11 & ATP-P11 & ++ & $1.5 \pm 0.3$ \\
\hline 12 & ATP-P12 & ++ & $0.5 \pm 0.1$ \\
\hline 13 & ATP-P13 & - & $0.4 \pm 0.1$ \\
\hline 14 & ATP-P14 & + & $0.6 \pm 0.1$ \\
\hline 15 & ATP-P15 & - & $0.7 \pm 0.1$ \\
\hline
\end{tabular}

(- No zone of clearance, + Zone of clearance, ++ Good zone of clearance, +++ Very good zone of clearance)

Table.2 Quantitative analysis of proteolytic bacteria isolated from the soil samples

\begin{tabular}{|c|c|c|c|c|}
\hline Organism & Casein Hydrolysis & $\begin{array}{c}\text { Activity } \\
(\mathbf{U} / \mathrm{ml})\end{array}$ & $\begin{array}{c}\text { Protein } \\
(\mathbf{m g} / \mathbf{m l})\end{array}$ & $\begin{array}{c}\text { Specific } \\
\text { Activity(U/mg) }\end{array}$ \\
\hline ATP-P5 & Positive & $\mathbf{2 . 0} \pm \mathbf{0 . 0 0 5}$ & $\mathbf{0 . 9} \pm \mathbf{0 . 0 0 1}$ & $\mathbf{2 . 0} \pm \mathbf{0 . 0 0 1}$ \\
\hline
\end{tabular}

Table.3 Biofilm produced by E.coli and Pseudomonas mendocina degraded by Protease enzyme

\begin{tabular}{|c|c|c|c|}
\hline S. No & Bacteria & $\begin{array}{c}\text { Treatment } \mathbf{A}_{660} \\
\text { (Biofilm+Enzyme) }\end{array}$ & $\begin{array}{c}\text { Control } \mathbf{A}_{660} \\
\text { (Biofilm) }\end{array}$ \\
\hline 1. & E.coli & $\mathbf{0 . 2 3 0 \pm 0 . 0 0 1}$ & $\mathbf{0 . 3 6 9 \pm 0 . 0 0 3}$ \\
\hline 2. & Pseudomonas mendocina & $\mathbf{0 . 1 2 0 \pm 0 . 0 0 1}$ & $\mathbf{0 . 2 9 2} \pm \mathbf{0 . 1 0}$ \\
\hline
\end{tabular}


Fig.1 Showing zone of hydrolysis around the colonies

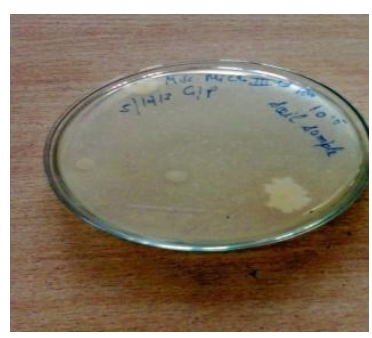

ATP-P1

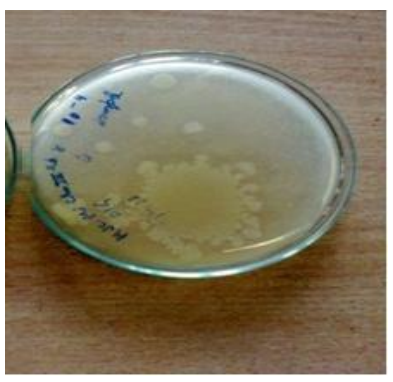

ATP-P6

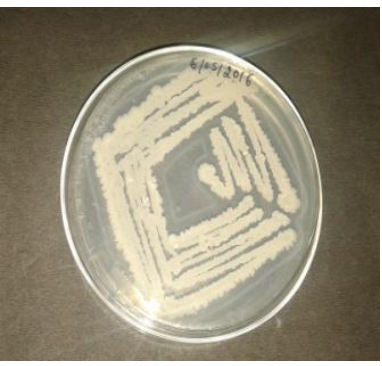

ATP-P12

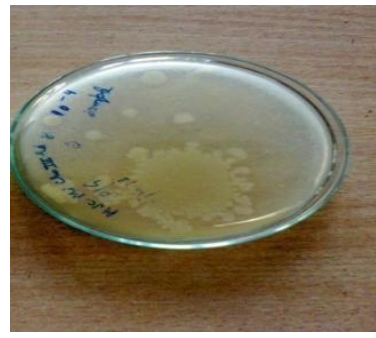

ATP-P3

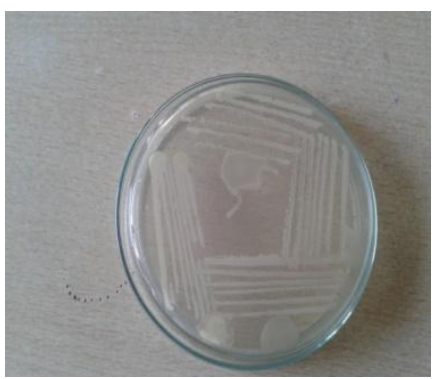

ATP-P7

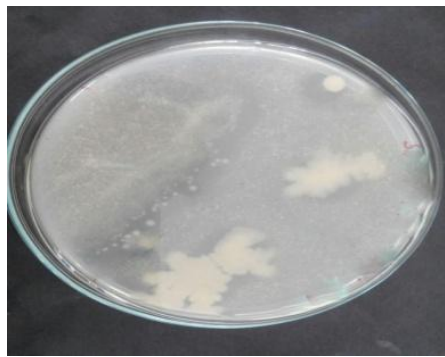

ATP-P14

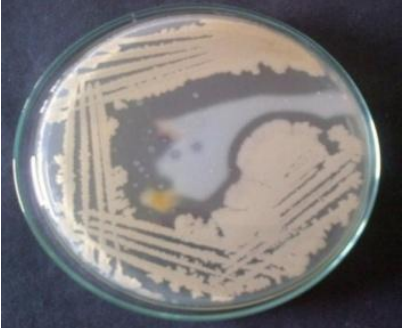

ATP-P5

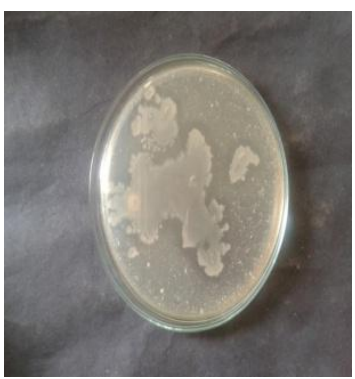

ATP-P11

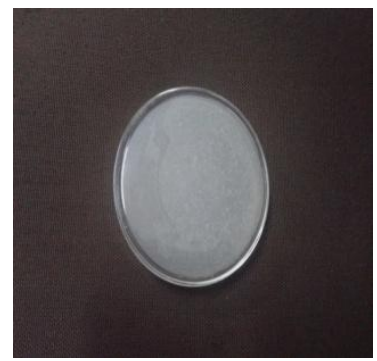

Control

Fig.2 Gram's staining of isolate ATP-P5

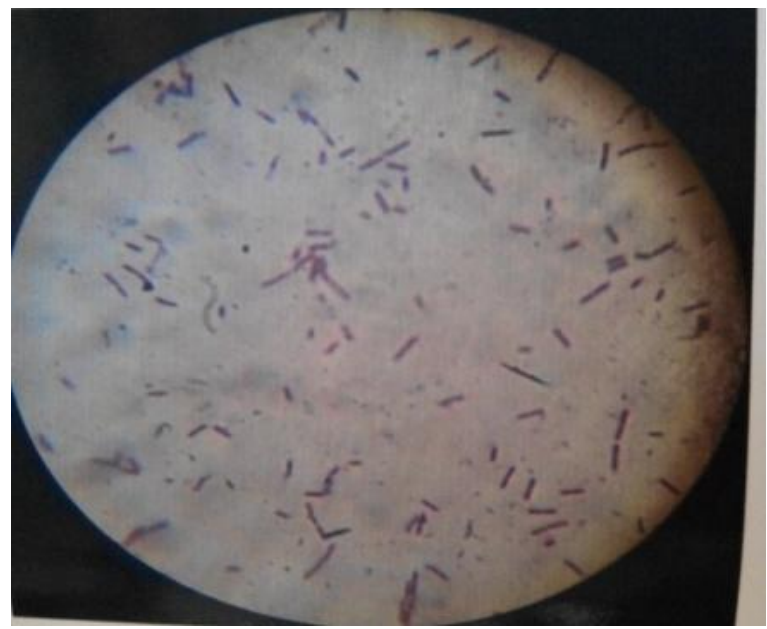


Fig.3 Spore staining of bacterial isolate ATP-P5 by method of Schaeffer and Fulton. Plate A: Presence of endospores (green colored) detected by Malachite green, magnification 1000X; and Plate B: Cropped and magnified view of the bacterial culture showing endospores

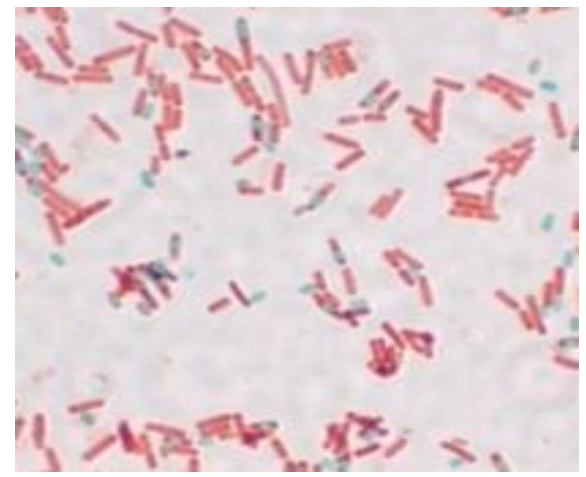

(A)

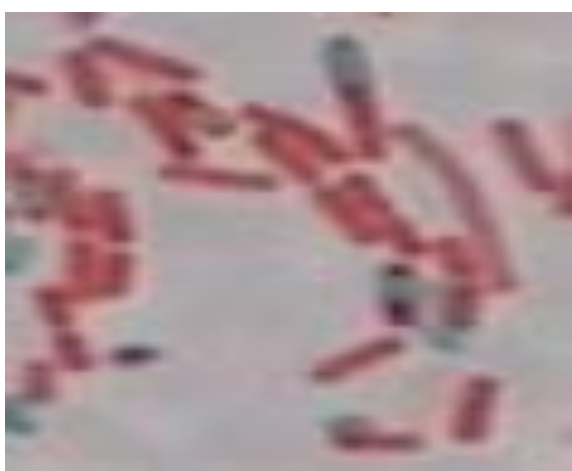

(B)

Fig.4 Lowery's Method

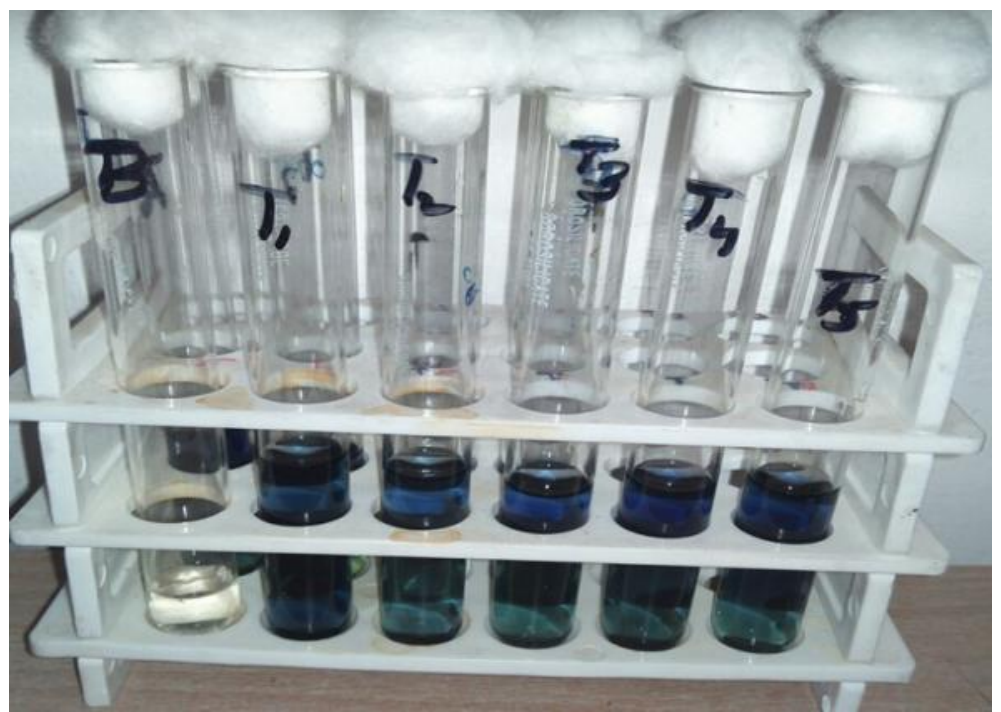

Fig.5 Tube method. Thick film formation gives positive result while thin film formation gives non biofilm producers

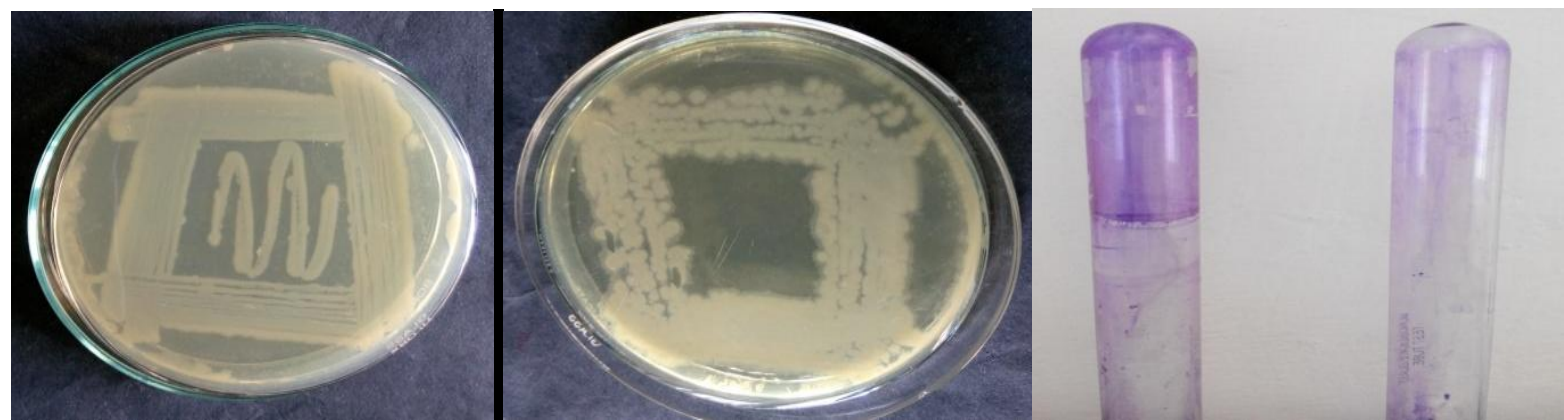

Figure 3.4. Growth of E.coli and Pseudomonas mendocina on Nutrient agar 
Fig.6 Congo red agar method Black colonies shows biofilm formation, while red colonies shows non biofilm producers

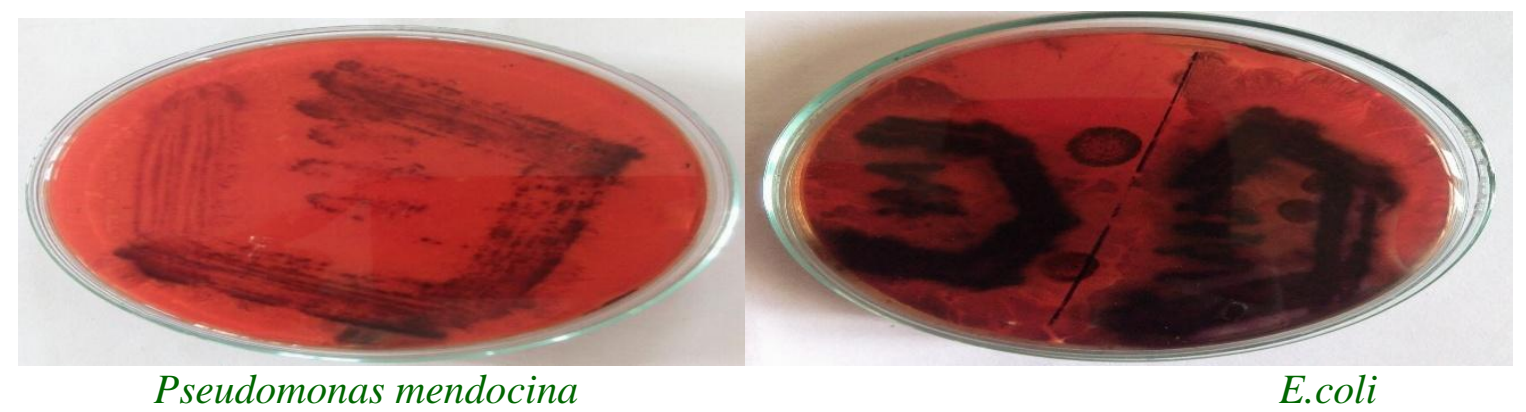

\section{Congo red agar method}

After using the Congo red in nutrient agar plates, black colour colonies were appeared on the nutrient agar plate which sows the presence of biofilm production from the organism (Fig 3.5).

On the congo red agar plate black color colonies shows biofilm formation, while red colonies were non biofilm producers (Figure 3.5). Biofilm formation degraded by using the protease enzyme in the reaction mixture. It is clear from the results (Table 3.3) that when biofilm was treated with the thermophilic protease enzyme the growth of bacteria producing biofilm was minimum (E.Coli 0.230 at $\mathrm{A} 660$ and Pseudomonas mendocina 0.120 at $\mathrm{A}_{660}$ ) as compared to control. Due to significant structural role of protease enzyme, and polysaccharides in the EPS (extracellular polymeric substance) in the matrix of bacteria producing biofilm. The combination of protease and polysaccharides was successful in biofilm removal or detachment of the organisms.

A total of 15 bacterial isolates were isolated from hot water and soil samples and out of these only 8 bacterial isolates hydrolyzed the casein. The maximum casein hydrolysis was observed with a bacterial isolate ATP-P5. There are many reports on isolation of protease producing microorganisms from soil
(Mahmoud et al., 2007, Palaniswamy et al., 2008; Kalaiarasi et al., 2009, Ashoken, 2010), tannery waste (Joshi, 2010), industrial effluent (Sangeetha et al., 2008; Feng et al., 2001). Adinarayana et al., (2003) reported quantitative screening of alkalophilic Bacilli for protease production by zone of clearance or precipitation of casein around the colonies. Isolate ATP-P5 was catalase, oxidase, lactose, glucose and sucrose positive whereas it was negative for indole test, methyl red test, vogus proskauer, citrate reduction and urease test. These phenotypic characteristics based on Bergey's Manual of Determinative Bacteriology confirmed the isolate ATP-P5 as Bacillus sp. This isolate was identified as Bacillus subtilis by $16 \mathrm{~S}$ ribotyping since it showed very close similarity with already existing $16 \mathrm{~S}$ sequences of Bacillus subtilis in the NCBI database. Results of the present study are conformity with the studies of Bajaj et al., 2013; Pravin et al., 2014; Pant et al., 2015 and Patil et al., 2015 they also reported the protease production from Bacillus species. However, Gupta et al., 2006 reported protease production from pseudomonas aeruginosa. Muthulakshmi et al., 2011 and Chaudhary et al., 2013 reported the protease production from Aspergillus species. Selecting the microorganism is important in order to obtain the desired product and its capability to secrete large amount of proteases and it should not produce toxins or any other undesirable products. 
Out of so many applications of this useful enzyme as discussed earlier in the literature, the present study has been conducted with the aim to evaluate its application on the biofilm degradation. The biofilms acts as a barrier for antibiotics to affect the pathogenic bacteria and this may account for some people developing chronic Borreliosis/ Lyme symptoms. Currently it is not scientifically known how to permanently degrade the biolfilm,

However it is known that proteolytic enzymes are very effective at dissolving mucupolysaccharides in biofilm. In the present study $0.2 \mathrm{ml}$ of purified protease has been applied for degrading the biofilm of Pseudomonas mendocina and E.coli in 10 minutes. Similar results had been reported by Bholey et al., (2012) who reported that enzyme of Bacillus pumilus and Staphylococcus auricularis was capable of degrading $86 \%$ and $50 \%$ of biofilm respectively. Molobela et al., (2010) used the combined effect of protease and amylase for the degradation of biofilm produced by Pseudomonas fluorescence bacteria. Singh et al., (2015) has reported that several fungi have capability to degrade biofilm by secreting various enzymes.

The purified protease was highly compatible with the detergents and help in removing protein based stain from clothes. Purified alkaline protease was also used for recovery of silver from waste X-Ray films and about $0.054 \mathrm{~g}$ silver was recovered from X-Ray film.

This indicated that alkaline protease from Bacillus subtilis has a potential of being applied for recovery of silver from waste XRay film as well as for biofilm degradation. In the present study $0.2 \mathrm{ml}$ of purified protease has been used for degradation of the biofilm from Pseudomonas mendocina and E.coli in 10 minutes.

\section{Acknowledgment}

I am thankful to UGC for providing funds to carry out the present investigation and I am also thankful to Department of Microbiology, Shoolini University Solan and Shoolini Institute of Life Sciences and Business Management Solan, (SILB) (India) for providing Infrastructure facilities for this study.

\section{References}

Adinarayana K, Ellaiah P, Prasad DS. 2003. Purification and partial characterization of thermostable serine alkaline protease from a newly isolated Bacillus subtilis PE-11. AAPS Pharmaceutical Science Technician. 3, 56-63.

Adinarayana K, Ellaiah P, Prasad DS. 2003. Purification and partial characterization of thermostable serine alkaline protease from a newly isolated Bacillus subtilis PE-11. AAPS Pharmaceutical Science Technician. 4, 56-63.

Aggarwal D, Patidar P, Banerjee T Patil S., 2012. Production of alkaline protease by Penicillium sp Under SSF conditions and its application to say Protein hydrolysis. Process Biochemistry. 39, 977-981.

Asokan S, Jayanth C., 2010. Alkaline protease production by Bacillus licheniformis and Bacillus coagulans. Journal of Cell and Tissue Research. 10(1), 2119-2123.

Bajaj BK, Jamwal G., 2013. Thermostable alkaline protease production from Bacillus pumilus D-6 by using agroresidues as substrates. Advances in Enzyme Research. 1(2), 30-6.

Banik RM, Prakash M., 2004. Laundry detergent compatibility of the alkaline protease from Bacillus cereus. Microbiology Resource.1, 135. 
Bholay AD, More SY, Patil VB, Patil N., 2012. Bacterial Extracellular Alkaline Proteases and its Industrial Applications. International Research Journal of Biological Science. 1(7), 1-5. Chaudhary V., 2013. Recovery of silver from used X-Ray films by Aspergillus versicolor protease. Journal of Academia and Indian research. 2(1), 391.

Cole SJ, Records AR, Orr MW, Linden SB, Lee VT., 2014. Catheter-Associated Urinary Tract Infection by Pseudomonas aeruginosa is mediated by Exopolysaccharide-Independent Biofilms. Infect Immun.82, 2048-2058.

Feng YY, Yang WB, Ong SL, Hu JY., 2001. Fermentation of starch for enhanced alkaline protease production by construction an alkaliphilic Bacillus pumilus strain. Applied Microbiology and Biotechnology. 57, 153-156.

Gupta A, Khare SK., 2006. A protease stable in organic solvents from solvent tolerant strain of Pseudomonas aeruginosa. Bioresource Technology. 97, 1788-3.

Ibrahim KS, Muniyandi J, Karutha Pandian S., 2011. Purification and characterization of a manganese dependent alkaline serine protease from Bacillus pumilus TMS55. Journal of Microbiology and Biotechnology. 21, 20-27.

Joshi B.H., 2010. Purification and characterization of a novel protease from Bacillus firmus isolated from tannery waste. Journal of Applied Science and Research. 8, 1068-6.

Kalaiarasi K, Sunitha PU., 2009. Optimization of alkaline protease production from Pseudomonas fluorescens isolated from meat waste contaminated soil. African Journal of Biotechnology. 8(24), 7035-7041.

Lowry OH, Rosebrough NH, Farr AL, Randall RL., 1951. Protein measurement with the folin phenol reagent. Journal of Biological Chemistry.193, 265-273.

Mahmoud MA, Agamy MHM, Ashour MS, Loboudy SS., 2007. Purification and characterization of neutral protease from soil strain of Bacillus subtilis. Bioresource Technology. 125, 132-133.

Molobela P, Cloete TE, Beukes M., 2010. Protease and amylase enzymes for biofilm removal and degradation of extracellular polymeric substance produced by Pseudomonas fluorescence bacteria. Africal Journal of Microbiology Research. 4(14), 30-37.

Muthulakshmi CD, Gomathi DG, Kumar G, Ravikumar G, Kalaiselvi M, Uma C., 2011. Production, purification and characterization of protease by Aspergillus flavus under solid state fermentation. Jordan journal of biological science. 4(3), 137-8.

Palaniswamy M, Pradeep BV, Sathya R, Angayarkanni J., 2008. Isolation, identification and screening of potential xylonolytic enzyme from litter degrading fungi. African Journal of Biotechnology. 2, 1978-1982.

Pant G, Prakash A, Pavani JVP, Sayantan B, Deviram GVNS, Kumar A, Panchpuri M, Parsuna RG., 2015. Production, optimization and partial purification of protease from Bacillus subtilis. Journal of Taibah University for Science. 9, 505.

Patil P, Sabale S, Devale A., 2015. Isolation and Characterization of Protease Producing Bacteria from Rhizosphere Soil and Optimization of Protease Production Parameters. International Journal of Current Microbiology and Applied Science. 2, 58-4.

Pravin D, Bhavasar S, Ghelani A, Bhatt S., 2014. Isolation, characterization and investing the industrial applications of thermostable and solvent tolerant serine 
protease from hot spring isolated thermophilic Bacillus licheniformis U1. International Journal of Applied Science and Biotechnology. 2(1), 75-2.

Ruzicka F, Hola V, Votava M., 2004. Biofilm detection and clinical significance of Staphylococcus epidermidis isolates. Folia Microbiol (Praha).49(5), 596-600.

Sangeetha R, Geetha A, Arulpandi I., 2008. Optimization of protease and lipase production by Bacillus pumilus SG 2 isolated from an industrial effluent. The Internet Journal of Microbiology. 5, 2-4. Singh SK, Singh SK, Tripathia VR, Khare SK, Garg SK., 2015. A novel psychrotrophic, solvent tolerant Pseudomonas putida SKG-1 and solvent stability of its psychrothermoalkalistable protease. Process Biochemistry. 46, 1430-1435.

\section{How to cite this article:}

Poonam Kumari, Savita Jandaik and Sudha Batta. 2018. Role of Extracellular Proteases in Biofilm Degradation Produced from Escherichia coli and Pseudomonas mendocina. Int.J.Curr.Microbiol.App.Sci. 7(06): 1786-1795. doi: https://doi.org/10.20546/ijcmas.2018.706.212 